\title{
Article \\ Effect of the Concentration of Extracellular Polymeric Substances (EPS) and Aeration Intensity on Waste Glycerol Valorization by Docosahexaenoic Acid (DHA) Produced in Heterotrophic Culture of Schizochytrium sp
}

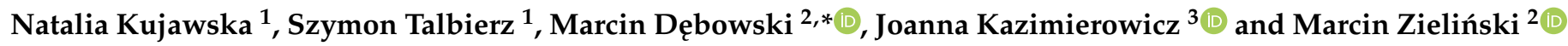 \\ 1 InnovaTree Sp. z o.o., 81-451 Gdynia, Poland; natalia.kujawska@innovatree.pl (N.K.); \\ szymon.talbierz@innovatree.pl (S.T.) \\ 2 Department of Environment Engineering, Faculty of Geoengineering, University of Warmia and Mazury in \\ Olsztyn, 10-720 Olsztyn, Poland; marcin.zielinski@uwm.edu.pl \\ 3 Department of Water Supply and Sewage Systems, Faculty of Civil Engineering and Environmental Sciences, \\ Bialystok University of Technology, 15-351 Bialystok, Poland; j.kazimierowicz@pb.edu.pl \\ * Correspondence: marcin.debowski@uwm.edu.pl
}

check for updates

Citation: Kujawska, N.; Talbierz, S.; Dębowski, M.; Kazimierowicz, J.;

Zieliński, M. Effect of the Concentration of Extracellular Polymeric Substances (EPS) and Aeration Intensity on Waste Glycerol Valorization by Docosahexaenoic Acid (DHA) Produced in Heterotrophic Culture of Schizochytrium sp. Appl. Sci. 2021, 11, 9573. https://doi.org/10.3390/ app11209573

Academic Editor: Cédric Delattre

Received: 3 September 2021

Accepted: 11 October 2021

Published: 14 October 2021

Publisher's Note: MDPI stays neutral with regard to jurisdictional claims in published maps and institutional affiliations.

Copyright: (c) 2021 by the authors. Licensee MDPI, Basel, Switzerland. This article is an open access article distributed under the terms and conditions of the Creative Commons Attribution (CC BY) license (https:// creativecommons.org/licenses/by/ $4.0 /)$.

\begin{abstract}
The study aimed to determine the effectiveness of docosahexaenoic acid (DHA) production by Schizochytrium sp. biomass fed with waste glycerol depending on the concentration of extracellular polymeric substances (EPS) in the culture medium and medium aeration effectiveness. The microalgae from the genus Schizochytrium sp. were proved to be capable of producing EPS composed of glucose, galactose, mannose, fucose, and xylose. The highest EPS concentration, reaching $8.73 \pm 0.09 \mathrm{~g} / \mathrm{dm}^{3}$, was determined at the stationary growth phase. A high EPS concentration caused culture medium viscosity to increase, contributing to diminished oxygen availability for cells, lower culture effectiveness, and reduced waste glycerol conversion to DHA. The Schizochytrium sp. culture variant found optimal in terms of the obtained technological effects and operating costs was performed at the volumetric oxygen mass transfer coefficient of $\mathrm{k}_{\mathrm{L}} \mathrm{a}=6001 / \mathrm{h}$, which enabled obtaining dry cell weight (DCW) of $147.89 \pm 4.77 \mathrm{~g} / \mathrm{dm}^{3}$, lipid concentration of $69.44 \pm 0.76 \mathrm{~g} / \mathrm{dm}^{3}$, and DHA concentration in the biomass reaching $29.44 \pm 0.36 \mathrm{~g} / \mathrm{dm}^{3}$. The effectiveness of waste glycerol consumption in this variant reached $3.76 \pm 0.31 \mathrm{~g} / \mathrm{dm}^{3} \cdot \mathrm{h}$ and $3.16 \pm 0.22 \mathrm{~g} / \mathrm{gDCW}$.
\end{abstract}

Keywords: waste glycerol; microalgae; Schizochytrium sp.; docosahexaenoic acid (DHA); extracellular polymeric substances (EPS); lipids

\section{Introduction}

Microalgae from the genus Schizochytrium sp. are known for producing valuable compounds, e.g., docosahexaenoic acid (DHA)-belonging to the Omega-3 family of fatty acids. So far, its main dietary sources have included fish flesh lipids and plant oils [1]. As the demand for Omega-3 family fatty acids increases due to the growing awareness of consumers and their care for a healthy lifestyle [2], a need emerges to search for competitive methods of their production that would be environmentally friendly as well as technologically and economically viable. The biomass of heterotrophic microalgae from the genus Schizochytrium sp. seems to offer a fine alternative in this respect [3].

To optimize, boost yield, and improve cost-effectiveness of DHA production by Schizochytrium sp., studies have analyzed multiple technological parameters having a significant impact on the final production results. These included: culture medium $\mathrm{pH}$ [4], temperature [5], turbine speed [6,7], nutrient concentration [8], oxygen concentration [9], initial inoculum concentration [10], and salinity [11]. Unfortunately, values of these basic parameters characterizing Schizochytrium sp. culture conditions determined under labora- 
tory conditions are not always consistent with respective values obtained from large-scale installations [12,13].

Inexpensive carbon sources offering an alternative to glucose are also searched for. Given the fact that Schizochytrium sp. biomass can grow on various carbon sources, including wastes, studies on the use of waste glycerol seem a justified prospective trend in scientific research [14]. So far, glycerol has been used as a carbon source in biochemical processes [15] and thermochemically converted to dipropylene glycol [16] and hydroxyacetone [17]. Other explored processes included its reformation to produce hydrogen and synthesis gas [18], esterification [19], hydrogenolysis [20], and production of epichlorohydrin [21]. Other ways of waste glycerol management for energetic purposes that have recently spurred great interest include production of ethanol (Saccharomyces cerevisiae) or $\beta$-carotene (Blakeslea trispora) [22-24].

Technological advance necessitates scale enlargement and verification of data obtained, that can be achieved via exploitation of pilot bioreactor installations followed by tests in the full technical scale [25-28]. During culture scale enlargement, it is impossible to keep all technological parameters at the levels established and employed in the laboratory scale $[29,30]$. Additionally, new difficulties and limitations often emerge, which determine the course and effectiveness of the whole process [31]. It is then indispensable to know the critical values of technological parameters having the greatest impact on the course of the entire incubation process [32]. One of the exploitation treatments posing severe difficulties in the large-scale facilities is the technologically and economically effective oxygen supply to bioreactors [33]. These difficulties stem from the cubature of facilities and growing viscosity of the culture medium during intensive production of Schizochytrium $\mathrm{sp}$. Biomass [34,35].

Fluid viscosity affects the mixing process, mass transfer, and gas diffusion in the culture medium, and consequently, the Reynold number value, and correlates with the oxygen mass transfer coefficient [36,37]. In high-density microbiological cultures with a high biomass concentration, the culture liquid turns viscous, which significantly influences hydrodynamics, heat and mass transfer, cell growth kinetics, and formation and accumulation of secondary metabolites in the culture medium [38-40]. It is believed that the increase in culture medium viscosity observed in the microorganism-mediated processes, including Schizochytrium sp., is largely due to the production of extracellular polymeric substances (EPS) [41,42]. Apart from technological difficulties and complications in establishing a commercial scale of high-density cultures, the viscosity increase caused by polysaccharide production may suppress lipid accumulation in cells and DHA production [43]. Therefore, it seems advisable to conduct a study to monitor culture viscosity and adjust aeration parameters to ensure the highest effectiveness of oxygen transfer to cells as the method of oxygen supply determines its solubility in the culture medium in aerobic biotechnological processes [44,45].

The study aimed to determine the effectiveness of a heterotrophic culture of Schizochytrium sp. fed with waste glycerol as an organic carbon source depending on the concentration and characteristics of extracellular polymeric substances (EPS) produced by the microalgal biomass and on medium aeration effectiveness. Experimental works aimed at verifying the influence of these parameters on the viscosity of the culture, the growth of biomass and the production of docosahexaenoic acid (DHA) were carried out on a laboratory scale.

\section{Methods}

\subsection{Materials}

The study used Schizochytrium sp. strain obtained from the ATCC (American Type Culture Collection). The method harnessed for preliminary biomass proliferation using the ATCC790By+ culture medium was presented in our previous works [46,47]. The exact experiment was conducted in a bioreactor with an active volume of $20 \mathrm{dm}^{3}$ (Biostat C, Sartorius Stedim, France). 


\subsection{Cultivation Conditions}

Crude glycerin, obtained from the PKN Orlen Południe S.A. Plant in Trzebinia, Poland, was used as the sole source of carbon in the cultures. The most important information from its characteristics' card (http:/ / www.rafineria-trzebinia.pl, accessed on 1 September 2021) is presented in Table 1.

Table 1. The properties and characteristics of the glycerol used in the experiments.

\begin{tabular}{|c|c|c|}
\hline Properties & Unit & Concentration \\
\hline Color & {$[-]$} & light-brown \\
\hline Odor & {$[-]$} & characteristic \\
\hline $\mathrm{pH}$ & {$[-]$} & 5 \\
\hline Glycerol & {$[\% w / w]$} & 80 \\
\hline Water & {$[\% w / w]$} & 15 \\
\hline Sulphated ash & {$[\% w / w]$} & 5 \\
\hline Methanol & {$[\% w / w]$} & 0.3 \\
\hline $\begin{array}{c}\text { MONG (Matter Organic Non } \\
\text { Glycerol) }\end{array}$ & {$[\% w / w]$} & 6 \\
\hline Chlorides & [ppm] & 10 \\
\hline Halogen derivatives & [ppm] & 35 \\
\hline Acidity & {$\left[\mathrm{cm}^{3}\right]$ of $\mathrm{NaOH}$ consumed } & 0.25 \\
\hline Esters & {$\left[\mathrm{cm}^{3}\right]$ of $\mathrm{NaOH}$ consumed } & $8-10$ \\
\hline Heavy metals & [ppm] & 5 \\
\hline Aldehydes & [ppm] & 10 \\
\hline $\begin{array}{l}\text { Temperature of } \\
\text { melting/freezing }\end{array}$ & {$\left[{ }^{\circ} \mathrm{C}\right]$} & 18 \\
\hline Temperature of initial boiling & {$\left[{ }^{\circ} \mathrm{C}\right]$} & 290 \\
\hline Temperature of ignition & {$\left[{ }^{\circ} \mathrm{C}\right]$} & 177 \\
\hline Temperature of self-ignition & {$\left[{ }^{\circ} \mathrm{C}\right]$} & 429 \\
\hline $\begin{array}{l}\text { Temperature of } \\
\text { decomposition }\end{array}$ & {$\left[{ }^{\circ} \mathrm{C}\right]$} & $>290$ \\
\hline Vapor pressure & [mbar] & 0.01 \\
\hline $\begin{array}{l}\text { Relative density/density } \\
\text { converted to } 20^{\circ} \mathrm{C}\end{array}$ & {$\left[\mathrm{kg} / \mathrm{dm}^{3}\right]$} & 1.26 \\
\hline Viscosity at $20^{\circ} \mathrm{C}$ & {$\left[\mathrm{mm}^{2} / \mathrm{s}\right]$} & 1.5 \\
\hline Density at $15^{\circ} \mathrm{C}$ & {$\left[\mathrm{kg} / \mathrm{dm}^{3}\right]$} & 1.2 \\
\hline Explosive properties & {$[-]$} & - \\
\hline
\end{tabular}

The culture was incubated for $120 \mathrm{~h}$, and the initial concentration of waste glycerol was $150 \mathrm{~g} / \mathrm{dm}^{3}$. Throughout the process, biomass samples were collected every $5 \mathrm{~h}$ and determined for the concentration of waste glycerol left in the culture medium. If the concentration was equal to or lower than $60 \mathrm{~g} / \mathrm{dm}^{3}$, fresh waste glycerol (density of $1.26 \mathrm{~g} / \mathrm{cm}^{3}$ ) was fed in the amount ensuring its concentration in the culture medium at $150 \mathrm{~g} / \mathrm{dm}^{3}$. The threshold glycerol concentration in the medium was established at $60 \mathrm{~g} / \mathrm{dm}^{3}$, because at this concentration Schizochytrium sp. entered into the stationary phase of growth $[46,47]$. Feeding the additional glycerol prevented Schizochytrium sp. from entering into the decline phase and allowed the continuous increase of lipid concentration in the biomass.

The other, initial culture conditions were established in our earlier optimization works $[46,47]$. The Plackett-Burman method and Response Surface Methodology were used for the two-stage identification. The modeled values of parameters and the expected final effects were verified in a laboratory scale [46]. The initial culture conditions were as follows: glycerol concentration $150 \mathrm{~g} / \mathrm{dm}^{3}$, temperature $27^{\circ} \mathrm{C}$, peptone concentration $10 \mathrm{~g} / \mathrm{dm}^{3}$, oxygen mass transfer rate $\mathrm{k}_{\mathrm{L}}$ a. $1501 / \mathrm{h}$, salinity $17.5 \mathrm{psu}$, culture $\mathrm{pH} 6.5$, yeast extract concentration $0.4 \mathrm{~g} / \mathrm{dm}^{3}$, turbine speed $185 \mathrm{rpm}$, and inoculum DCW $5.0 \mathrm{~g} / \mathrm{dm}^{3}$.

As culture medium viscosity significantly affects oxygen transport to cells, and, consequently, the value of oxygen mass transfer rate $\left(k_{L} a\right)$, it turned out necessary to verify 
those initial culture conditions, which have a direct impact on its values, i.e., turbine speed and volumetric air flow rate (the other culture parameters remained unchanged). Given the above, five cultures were performed differing in $\mathrm{k}_{\mathrm{L}}$ a values due to the modification of mixing and aeration conditions. Afterward, the final biomass concentration, lipid, and DHA concentration were determined for these cultures. The results obtained allowed determining the rate of DHA production by microalgae $\left(\mathrm{r}_{\mathrm{DHA}}\right)$ and the growth rate of the microalgal biomass $\left(r_{D C W}\right)$. The values of mixing and aeration parameters used in the successive experimental variants are presented in Table 2.

Table 2. The $\mathrm{k}_{\mathrm{L}}$ a values and conditions of Schizochytium sp. culture mixing and aeration used in the study.

\begin{tabular}{ccccc}
\hline Culture Variant & $\begin{array}{c}\mathbf{k}_{\mathbf{L}} \mathbf{a} \\
{[\mathbf{1} / \mathbf{h}]}\end{array}$ & $\begin{array}{c}\text { Turbine Speed } \\
{[\mathbf{r p m}]}\end{array}$ & $\begin{array}{c}\text { Volumetric Air } \\
\text { Flow Rate } \\
{\left[\mathbf{d m}^{\mathbf{3}} \mathbf{/ h}\right]}\end{array}$ & $\begin{array}{c}\text { Bioreactor Tank } \\
\text { Volume } \\
{\left[\mathbf{d m}^{\mathbf{3}}\right]}\end{array}$ \\
\hline 1 & 150 & 185 & 0.80 & 20.0 \\
2 & 300 & 370 & 1.60 & 20.0 \\
3 & 450 & 555 & 2.40 & 20.0 \\
4 & 600 & 740 & 3.20 & 20.0 \\
5 & 750 & 925 & 4.00 & 20.0 \\
\hline
\end{tabular}

\subsection{Analytical Methods}

Determinations of: glycerol concentration in the culture medium, dry cell weight (DCW) of microalgae, and lipid concentration in the biomass, as well as the qualitative analysis of microalgal biomass fatty acids were conducted following the methodology presented in our previous works [46,47]. Crude glycerol concentration in the culture medium was determined by centrifugation $\left(8000 \times g, 4 \mathrm{~min}, 10{ }^{\circ} \mathrm{C}\right.$; UNIVERSAL $320 \mathrm{R}$ centrifuge, Hettich, Tuttlingen, Germany) and analysis of the supernatant using the Glycerol GK Assay Kit (Megazyme, Bray, Ireland). The concentration of nicotinamide adenine dinucleotide (NADH) was measured spectrophotometrically (Multiskan GO Microplate, Thermo Scientific, Vantaa, Finland) at a wavelength of $340 \mathrm{~nm}$. The dry cell weight (DCW) of the microalgae was determined from the concentrated biomass that was washed twice with distilled water, then dried at $60^{\circ} \mathrm{C}$ for $12 \mathrm{~h}$ in a moisture balance (MAR, Radwag, Poland) to stabilize the biomass. The lipid content of the biomass was determined by adding a hydrochloric acid solution to freeze-dried biomass (ALPHA 1-4 LD plus freeze dryer, Christ), which was then placed in a water bath (GFL 1003) at $75{ }^{\circ} \mathrm{C}$ for $40 \mathrm{~min}$. The sample was treated with $n$-hexane for lipid extraction and placed in a vacuum evaporator (HeiVAP Advantage G3, Heidolph, Schwabach, Germany) to evaporate the solvent. The lipid content of the sample was measured gravimetrically. The determination of fatty acids was done using a modified direct transmethylation method. The organic phase containing fatty acid methyl esters (FAME) was harvested and analyzed by chromatography (Clarus 680 GC (Perkin Elmer, Waltham, MA, USA) gas chromatograph) [46,47].

Culture viscosity was determined using a Cannon-Fenske capillary viscosimeter (SCHOTT, Mainz, Germany). The $\mathrm{k}_{\mathrm{L}}$ a value was determined using a method described by Swaaf et al. (2001) [40]. To this end, two solutions were prepared, including a supernatant of the culture medium and a solution of marine salt having the same concentration as in the culture medium (reference solution). To decrease partial pressure to $2 \%$ in both solutions, they were flushed with nitrogen. Then, each solution was aerated at the rate of $5 \mathrm{dm}^{3} / \mathrm{min}$ and mixed at the speed of $300 \mathrm{rpm}$. The $\mathrm{k}_{\mathrm{L}}$ a value was determined as the inclination of the curve of partial oxygen concentration in the solution dependence on time.

Samples $\left(5 \mathrm{~cm}^{3}\right)$ of the Schizochytrium sp. culture were collected, transferred to a centrifuge tube, and centrifuged at a room temperature for $12 \mathrm{~min}$ at $15,000 \times g$ (UNIVERSAL $320 \mathrm{R}$, Hettich). After completed centrifugation, the supernatant was determined for the concentration of saccharides representing the polymeric part of EPS, i.e., the so-called nonattached EPS [48]. The saccharides were isolated from the supernatant by 12-h precipitation 
in cold ethanol $\left(-20^{\circ} \mathrm{C}\right)$, the final concentration of which after sample addition reached $80 \%$, and then by nitrogen drying. Afterward, their concentration was determined using the phenol-sulfate method [49]. To this end, a $1-\mathrm{cm}^{3}$ sample of precipitated polysaccharides dissolved in distilled water was collected, to which $1 \mathrm{~cm}^{3}$ of a $5 \%$ phenol solution was added, and the whole sample was mixed at the speed of approximately $1250 \mathrm{rpm}$ (Vortex Reax top, Heidolph). Next, $5 \mathrm{~cm}^{3}$ of concentrated $\mathrm{H}_{2} \mathrm{SO}_{4}$ were added using an automatic pipette, and the sample was again mixed at the speed of approximately $1000 \mathrm{rpm}$ (Vortex Reax top, Heidolph) and left to stand. After $10 \mathrm{~min}$, the sample was mixed again and placed in a water bath with a temperature of $27^{\circ} \mathrm{C}$ for $15 \mathrm{~min}$ (GFL 1003 digital water bath). After the fixed time, the sample was shaken, and then its absorbance was measured at the wavelength of $488 \mathrm{~nm}$ (Multiskan GO Microplate spectrophotometer, Thermo Scientific), using a glucose solution as a standard solution.

The composition of monosaccharides constituting the EPS polysaccharide fraction was analyzed with the gas chromatography method. To this end, the polysaccharide fraction of extracellular EPS was hydrolyzed, whereas saccharide monomers were methylated with acid methanol containing $2 \mathrm{M} \mathrm{HCl}$. The hydrolysis was continued for $16 \mathrm{~h}$ at a temperature of $85^{\circ} \mathrm{C}$. The resulting samples, containing methylglycosides, were converted into trimethylsilyl derivatives and separated in a silica column $(30 \mathrm{~m} \times 0.25 \mathrm{~mm} \times 0.25 \mu \mathrm{m})$ in a chromatograph (Perkin Elmer, Clarus 680 GC) equipped in a split-splitless injector and a flame ionization detector (FID), according to the method by Chaplin and Kennedy (1986) [50]. Injector's and detector's temperatures were set at 220 and $250{ }^{\circ} \mathrm{C}$, respectively. Pure helium was used as a carrier gas, at the flow rate of $25-30 \mathrm{~cm}^{3} / \mathrm{min}$, whereas mannitol was used as the internal standard.

\subsection{Statistical Analysis}

All experiments were conducted in four replications. Measurements of the analyzed parameters and indicators were carried out in duplicate or triplicate depending on the repeatability of the obtained results. The statistical analysis of experimental results was carried using a STATISTICA 13.1 PL package. One-way analysis of variance (ANOVA) was performed to determine the significance of differences between variables. HSD Tukey test was used for post hoc analysis. In the tests, results were considered significant at $\alpha=0.05$.

\section{Results and Discussion}

\subsection{EPS Concentration and Composition}

Many factors determine EPS production by microorganisms, including nutrients present in the culture medium - such as carbon or nitrogen [51,52] and their concentration ratio, and also physical parameters, such as temperature, $\mathrm{pH}$, or mixing speed [53,54]. EPS are essential for proper microalgae growth in the medium as they increase their mobility, serve as a carbon source for bacteria and microfauna, and finally elicit various effects on physical and chemical parameters of the culture medium, including porosity, mechanical stability, or density $[55,56]$. Besides, they preserve the structure of cell aggregates and protect them against drying out [57].

During the culture of Schizochytrium sp. biomass under optimized initial conditions, culture medium viscosity increased from $7.15 \pm 0.91 \mathrm{~mm}^{2} / \mathrm{s}$ to $20.97 \pm 0.74 \mathrm{~mm}^{2} / \mathrm{s}$. Its most dynamic increase, from $11.11 \pm 0.17 \mathrm{~mm}^{2} / \mathrm{s}$ to $17.77 \pm 0.16 \mathrm{~mm}^{2} / \mathrm{s}$, was observed from the $60 \mathrm{~h}$ of incubation till the culture reached the stationary growth phase (Figure 1). A linear correlation was found between DCW of Schizochytrium sp. biomass, viscosity of the culture medium, and EPS concentration (Figure 2). After $120 \mathrm{~h}$ of incubation, DCW concentration reached $103.44 \pm 1.5 \mathrm{~g} / \mathrm{dm}^{3}$ (Figure 1). The initial EPS concentration in the culture medium was at $2.93 \pm 0.11 \mathrm{~g} / \mathrm{dm}^{3}$ and increased to $4.63 \pm 0.14 \mathrm{~g} / \mathrm{dm}^{3}$ in the $60 \mathrm{~h}$ of incubation. Afterward, the Schizochytrium sp. population reached the stage of the stationary growth, which determined a ramped increase in EPS concentration to $7.25 \pm 0.11 \mathrm{~g} / \mathrm{dm}^{3}$, followed by its stabilization, and its final concentration of $8.73 \pm 0.09 \mathrm{~g} / \mathrm{dm}^{3}$ after $120 \mathrm{~h}$ of incubation (Figure 1). Different reviews concerning microalgae EPS production have been published [58,59]. Most of results 
were obtained in laboratory, with perfectly controlled conditions. Both the EPS productivity and the EPS concentration in the culture medium vary significantly depending on the strain studied. Nevertheless, the maximum productivity found in literature for a cyanobacteria (Anabanea sp.) is $2.9 \mathrm{~g} / \mathrm{dm}^{3} / \mathrm{d}$, for a microalga grown in autotrophy (Porphyridium sp.) is $0.19 \mathrm{~g} / \mathrm{dm}^{3} / \mathrm{d}$ and for a microalga grown in heterotrophy (Chlorella $\mathrm{sp}$.) is $0.36 \mathrm{~g} / \mathrm{L} / \mathrm{d}$. The average concentrations are most of the time between 0.5 and $1 \mathrm{~g} / \mathrm{dm}^{3}$ [60]. Jain et al. (2005) [61] observed a lower yield of EPS production by microalgae from the Thraustochytriacae family, reaching $0.3-1.1 \mathrm{~g} / \mathrm{dm}^{3}$, compared to that determined in the present study. Additionally, Chang et al. (2014) [62] reported on the possibility of EPS production by the biomass Schizochytrium sp. S31 and the effect of this process on the increase in the viscosity of the culture medium.

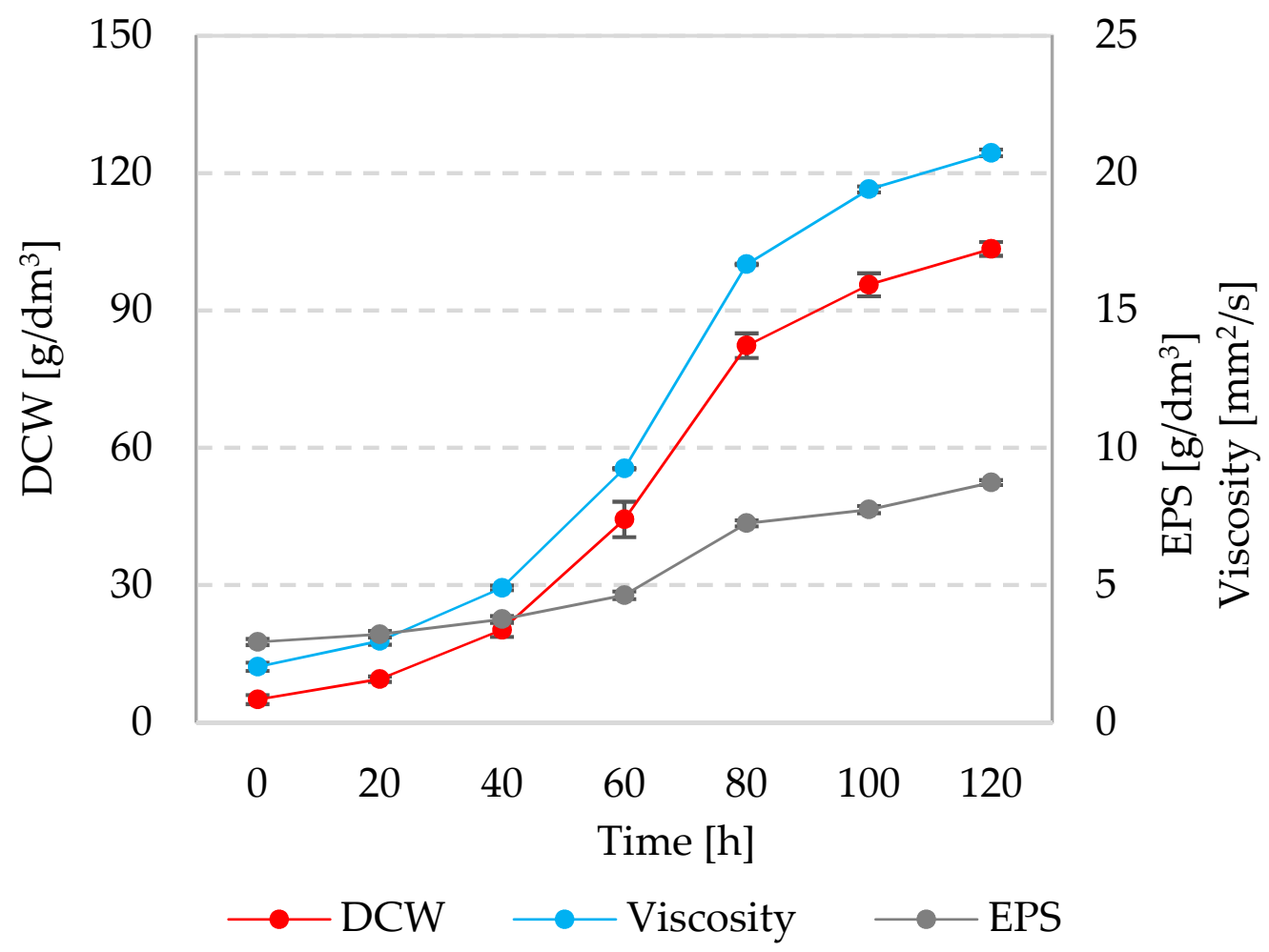

Figure 1. Changes in Schizochytrium sp. DCW concentration, medium viscosity, and EPS concentration in the culture medium during incubation.

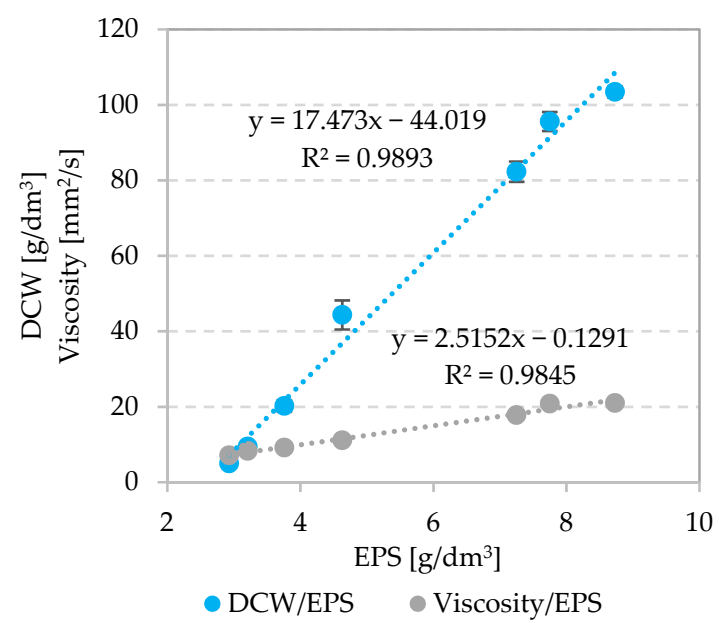

Figure 2. Dependence of DCW and medium viscosity on EPS fraction concentrations culture. 
Concentrations of saccharide monomers of the EPS fraction remained stable over the incubation period. The monosaccharides present in the EPS fraction included hexoses, except for xylose which is classified among pentoses. The major monosaccharide turned out to be glucose, with the concentration accounting for $60.64 \pm 1.93 \% \mathrm{~mol}$. In contrast, the lowest concentration, reaching $2.66 \pm 1.28 \%$ mol, was found for xylose. The qualitative and quantitative composition of monomer saccharides is presented in Table 3 . Similar conclusions were formulated by Jain et al. (2005) [61], who additionally demonstrated that glucose, galactose, mannose, and xylose of the EPS fraction were constituents of the cell walls of the Thraustochytriacae family microalgae.

Table 3. Composition of saccharide monomers of the EPS polysaccharide fraction.

\begin{tabular}{cc}
\hline Saccharide Monomer & Molar Percentage [\% mol] \\
\hline Glucose & $60.64 \pm 1.93$ \\
Galactose & $18.00 \pm 1.13$ \\
Mannose & $11.47 \pm 0.71$ \\
Fucose & $7.23 \pm 0.62$ \\
Xylose & $2.66 \pm 1.28$ \\
\hline
\end{tabular}

\subsection{Effect of Oxygen Mass Transfer Rate $(k \mathrm{~L} a)$ on Culture Technological Effectiveness}

The method of oxygen supply determines its solubility in the culture medium in aerobic biotechnological processes $[44,63]$. Investigations conducted thus far have shown that providing the appropriate oxygen supply to the culture significantly increases the growth of Schizochytrium sp. cells and DHA synthesis in the biomass [35,62,64]. Oxygen transfer to cells has been found to be strongly affected by culture medium viscosity, whose increase observed in microbiological cultures is due to EPS synthesis [65].

The increased viscosity of the culture medium diminishes the effectiveness of oxygen transfer to cells, which affects the effectiveness of waste glycerol consumption and its conversion to DHA. Hence, it is essential to search for a method of air supply to the system that would be justified by both final technological effects and operating costs.

Regardless of the applied $\mathrm{k}_{\mathrm{L}}$ a coefficient value, each culture entered into three growth phases: adaptation phase (1) spanning from 0 to 40 th hour, logarithmic growth phase (2) observed between the 40th hour and 80th-100th hour, and stationary growth phase (3) observed since the 80th-100th hour to 120th hour of incubation. In the variant with $\mathrm{k}_{\mathrm{L}} \mathrm{a}=1501 / \mathrm{h}$, biomass DCW increased from $5.0 \pm 1.0 \mathrm{~g} / \mathrm{dm}^{3}$ to $22.42 \pm 1.09 \mathrm{~g} / \mathrm{dm}^{3}$ in phase 1 , from $22.42 \pm 1.09 \mathrm{~g} / \mathrm{dm}^{3}$ to $87.60 \pm 2.79 \mathrm{~g} / \mathrm{dm}^{3}$ in phase 2 , and reached the final value of $112.77 \pm 2.65 \mathrm{~g} / \mathrm{dm}^{3}$ in phase 3 (Figures $3 \mathrm{a}$ and 4 , Table 4 ). The concentrations of lipids and DHA peaked in the logarithmic growth stage to reach the final values of $48.90 \pm 1.56 \mathrm{~g} / \mathrm{dm}^{3}$ and $21.02 \pm 0.73 \mathrm{~g} / \mathrm{dm}^{3}$, respectively (Figure 4 ). Similar values of biomass production, lipid accumulation, and DHA synthesis were obtained in variant 2 with $\mathrm{k}_{\mathrm{L}} \mathrm{a}=3001 / \mathrm{h}$ (Figures $3 \mathrm{~b}$ and 4, Table 4). Glycerol consumption yield in both these variants approximated $3.6 \mathrm{~g} / \mathrm{dm}^{3} \cdot \mathrm{h}$ and $4.0 \mathrm{~g} / \mathrm{gDCW}$ (Table 4). Ren et al. (2010) [35] confirmed in their study that $\mathrm{k}_{\mathrm{L}} \mathrm{a}=1501 / \mathrm{h}$ promoted cell growth within the first $40 \mathrm{~h}$ of incubation and that decreasing the value of this coefficient to $88.51 / \mathrm{h}$ increased final DHA concentration in cells. The above observations were presumably due to the microalgae capability for lipid accumulation under conditions of substrate stress [66]. In the culture of Schizochytrium sp. described by Chang et al. (2013) [67], the use of $\mathrm{k}_{\mathrm{L}} \mathrm{a}=143 \pm 191 / \mathrm{h}$ ensured biomass DCW concentration at $25.56 \pm 1.60 \mathrm{~g} / \mathrm{dm}^{3}$ and DHA concentration at barely $2.28 \mathrm{~g} / \mathrm{dm}^{3}$. The low values of the above parameters can be explained by poor availability of oxygen molecules to microalgal cells and, consequently, by the impaired metabolic activity in the cycle of tricarboxylic acid or/and lipogenesis. 
(a)

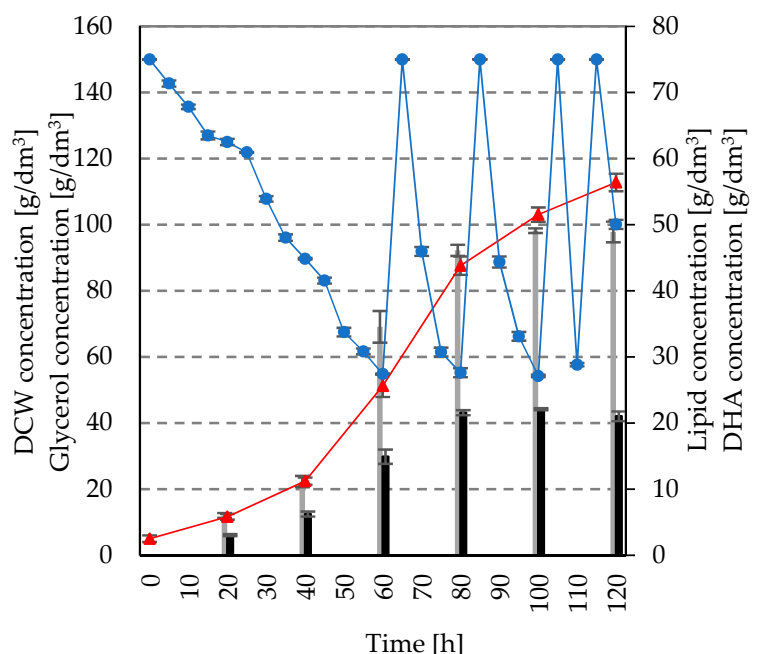

(c)

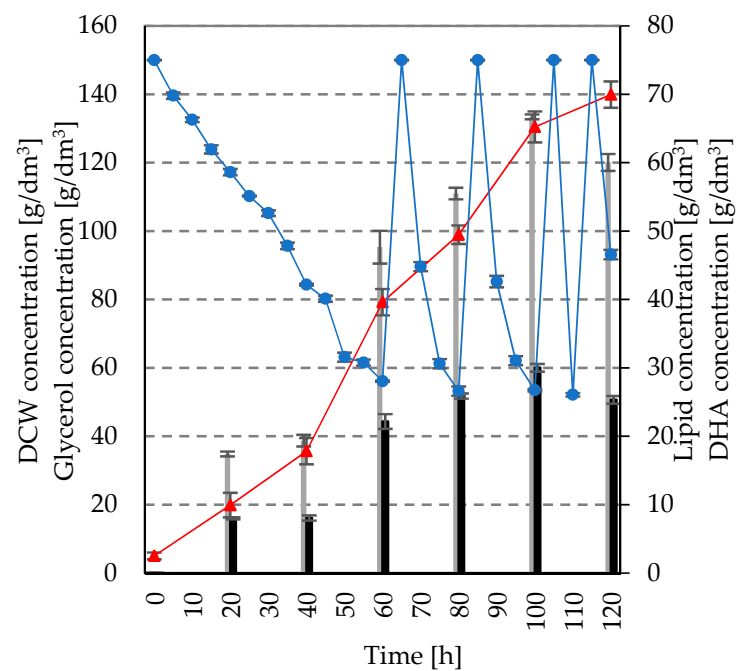

(e)

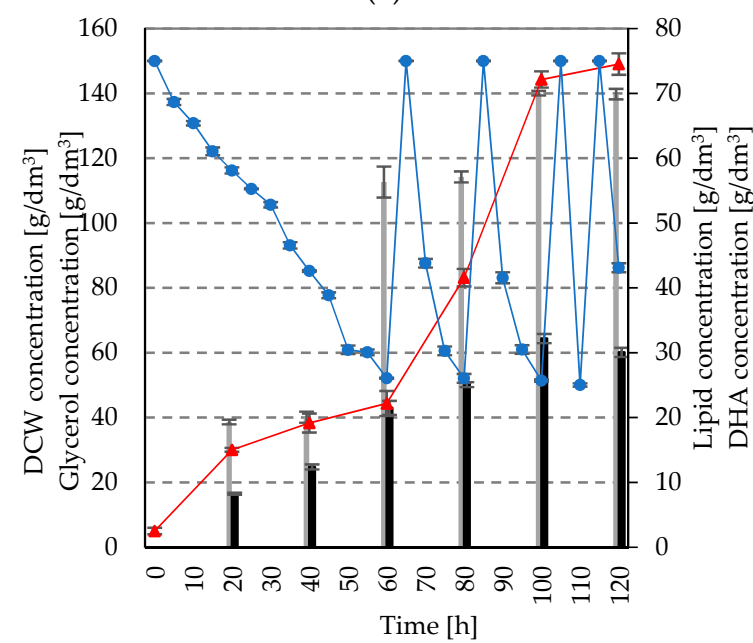

(b)

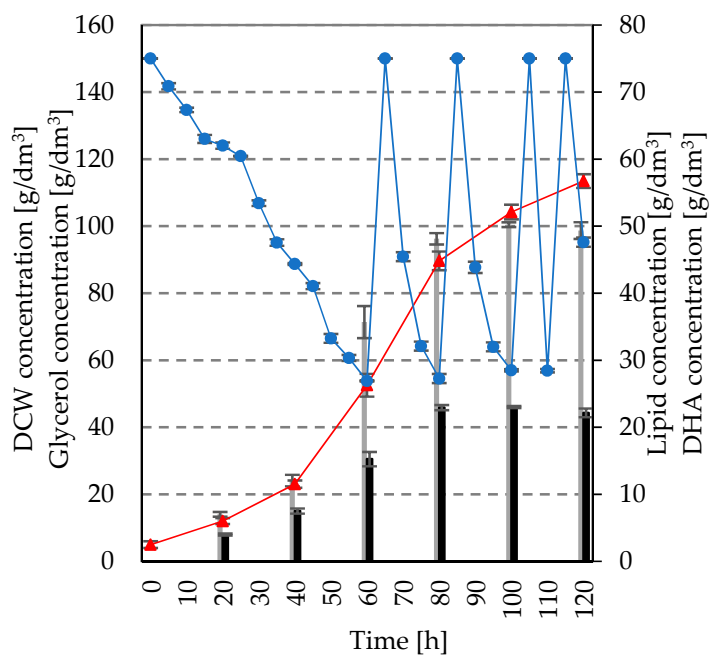

(d)

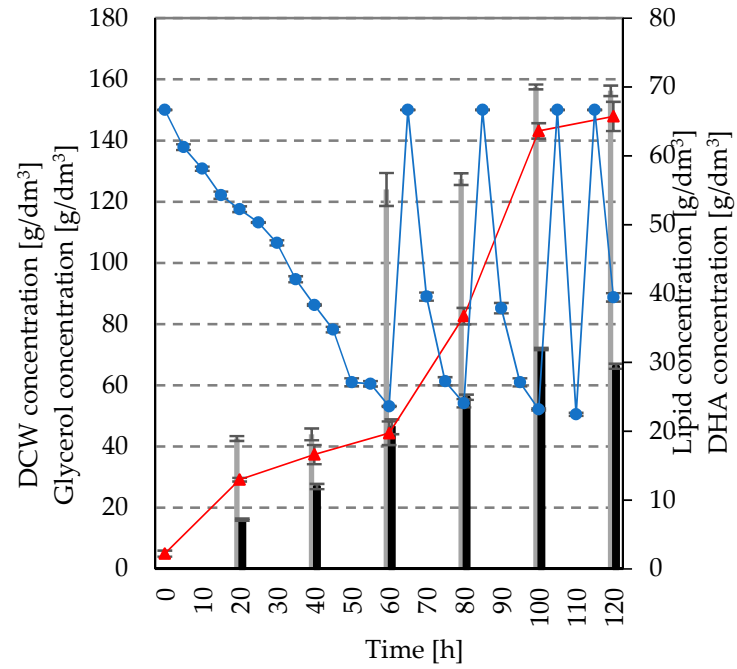




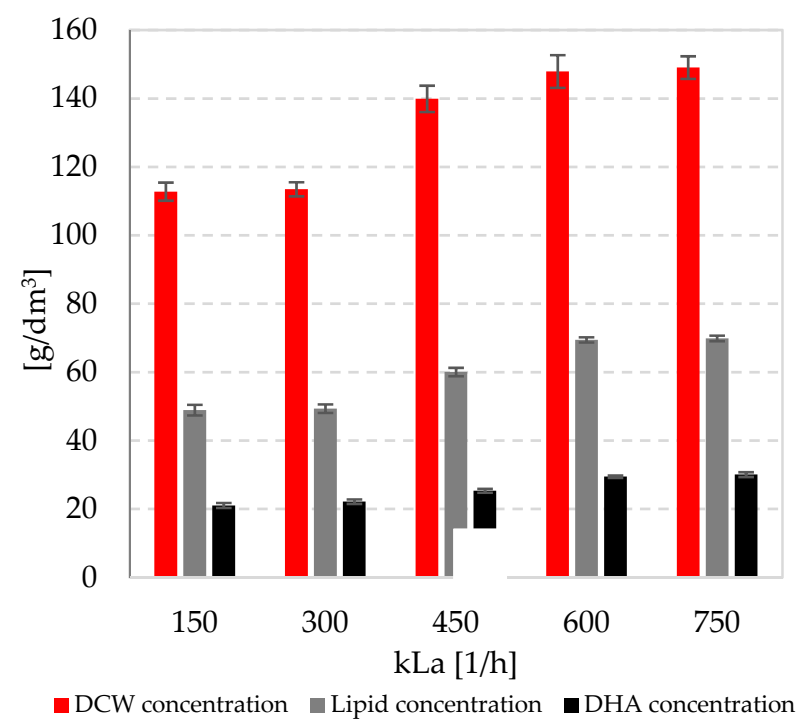

Figure 4. Concentrations of DCW, DHA, and lipids depending on $\mathrm{k}_{\mathrm{L}}$ a value.

Table 4. Parameters characterizing the effectiveness of Schizochytrium sp. culture depending on $\mathrm{k}_{\mathrm{L}}$ a value.

\begin{tabular}{|c|c|c|c|c|c|c|}
\hline Parameter & Unit & $\begin{array}{c}k_{L} a=150 \\
{[1 / h]}\end{array}$ & $\begin{array}{c}\mathrm{k}_{\mathrm{L}} \mathrm{a}=300 \\
{[1 / \mathrm{h}]}\end{array}$ & $\begin{array}{c}\mathrm{k}_{\mathrm{L}} \mathrm{a}=450 \\
{[1 / \mathrm{h}]}\end{array}$ & $\begin{array}{c}\mathrm{k}_{\mathrm{L}} \mathrm{a}=600 \\
{[1 / \mathrm{h}]}\end{array}$ & $\begin{array}{c}\mathrm{k}_{\mathrm{L}} \mathrm{a}=750 \\
{[1 / \mathrm{h}]}\end{array}$ \\
\hline Time [h] & {$[\mathrm{h}]$} & 120 & 120 & 120 & 120 & 120 \\
\hline DCW & {$\left[\mathrm{g} / \mathrm{dm}^{3}\right]$} & $112.77 \pm 2.65$ & $113.45 \pm 2.05$ & $139.90 \pm 3.86$ & $147.89 \pm 4.77$ & $149.03 \pm 3.31$ \\
\hline $\begin{array}{c}\text { Lipid } \\
\text { concentration }\end{array}$ & {$\left[\mathrm{g} / \mathrm{dm}^{3}\right]$} & $48.90 \pm 1.56$ & $49.34 \pm 1.25$ & $60.03 \pm 1.24$ & $69.44 \pm 0.76$ & $69.88 \pm 0.81$ \\
\hline DHA & {$\left[\mathrm{g} / \mathrm{dm}^{3}\right]$} & $21.02 \pm 0.73$ & $22.15 \pm 0.65$ & $25.32 \pm 0.56$ & $29.44 \pm 0.36$ & $30.05 \pm 0.71$ \\
\hline $\mathrm{r}_{\mathrm{DCW}}$ & {$\left[\mathrm{g} / \mathrm{dm}^{3} \cdot \mathrm{h}\right]$} & $0.94 \pm 0.15$ & $0.95 \pm 0.09$ & $1.17 \pm 0.21$ & $1.23 \pm 0.25$ & $1.24 \pm 0.13$ \\
\hline $\mathrm{r}_{\mathrm{DHA}}$ & {$\left[\mathrm{g} / \mathrm{dm}^{3} \cdot \mathrm{h}\right]$} & $0.18 \pm 0.08$ & $0.18 \pm 0.05$ & $0.21 \pm 0.02$ & $0.25 \pm 0.15$ & $0.25 \pm 0.09$ \\
\hline Glycerol & {$\left[\mathrm{g} / \mathrm{dm}^{3} \cdot \mathrm{h}\right]$} & $3.57 \pm 0.32$ & $3.60 \pm 0.26$ & $3.68 \pm 0.28$ & $3.76 \pm 0.31$ & $3.82 \pm 0.19$ \\
\hline consumption & {$[\mathrm{g} / \mathrm{gDCW}]$} & $3.97 \pm 0.76$ & $3.99 \pm 0.64$ & $3.28 \pm 0.59$ & $3.16 \pm 0.22$ & $3.18 \pm 0.15$ \\
\hline EPS & {$\left[\mathrm{g} / \mathrm{dm}^{3}\right]$} & $8.73 \pm 0.09$ & $8.62 \pm 0.12$ & $8.94 \pm 0.06$ & $9.17 \pm 0.23$ & $9.08 \pm 0.17$ \\
\hline Viscosity & {$\left[\mathrm{mm}^{2} / \mathrm{s}\right]$} & $20.97 \pm 0.74$ & $21.03 \pm 1.02$ & $21.33 \pm 0.68$ & $21.07 \pm 0.91$ & $21.43 \pm 1.13$ \\
\hline
\end{tabular}

In the culture variant with $\mathrm{k}_{\mathrm{L}} \mathrm{a}=4501 / \mathrm{h}$, DCW of microalgae increased from $5.0 \pm 1.0 \mathrm{~g} / \mathrm{dm}^{3}$ to $35.63 \pm 3.83 \mathrm{~g} / \mathrm{dm}^{3}$ in the adaptation phase, while at the end of phase 2 (after $100 \mathrm{~h}$ of incubation) it reached $130.46 \pm 4.53 \mathrm{~g} / \mathrm{dm}^{3}$. The stationary growth phase yielded the DCW concentration of $139.90 \pm 3.86 \mathrm{~g} / \mathrm{dm}^{3}$ at the end of the incubation cycle (Figures 3c and 4, Table 4). In turn, the logarithmic growth stage brought about the most intense processes of lipid accumulation in cells and DHA synthesis (Figure 3c). Their final concentrations in the biomass reached $60.03 \pm$ $1.24 \mathrm{~g} / \mathrm{dm}^{3}$ and $25.32 \pm 0.56 \mathrm{~g} / \mathrm{dm}^{3}$, respectively (Figure 4, Table 4). In this variant, on average $442.0 \mathrm{~g} / \mathrm{dm}^{3}$ of glycerol were fed to bioreactors during the entire incubation cycle, resulting in its consumption yield at $3.68 \mathrm{~g} / \mathrm{dm}^{3} \cdot \mathrm{h}, 3.28 \mathrm{~g} / \mathrm{gDCW}$ (Table 4).

The best, statistically comparable technological effects associated with DCW increase, lipid synthesis, and DHA accumulation in cells were observed in the culture variants 4 and 5 with $\mathrm{k}_{\mathrm{L}}$ a values ranging from $6001 / \mathrm{h}$ to $7501 / \mathrm{h}$. After $40 \mathrm{~h}$ of the adaptation phase, the DCW of Schizochytrium sp. reached $37.37 \pm 3.14 \mathrm{~g} / \mathrm{dm}^{3}$ in variant 4 and $38.31 \pm 2.92 \mathrm{~g} / \mathrm{dm}^{3}$ in variant 5 . After $120 \mathrm{~h}$, the respective values reached $147.89 \pm 4.77 \mathrm{~g} / \mathrm{dm}^{3}$ (Figures $3 \mathrm{~d}$ and 4 , Table 4) and $149.03 \pm 3.31 \mathrm{~g} / \mathrm{dm}^{3}$ (Figures $3 \mathrm{e}$ and 4, Table 4). The final lipid concentration was determined at approximately $70.0 \mathrm{~g} / \mathrm{dm}^{3}$, whereas the final DHA concentration in biomass approximated $30.0 \mathrm{~g} / \mathrm{dm}^{3}$ (Figures $3 \mathrm{~d}$,e and 4 , Table 4). Increasing the volumetric oxygen mass transfer rate and turbine speed in these variants contributed to the highest recorded values of $\mathrm{r}_{\mathrm{DHA}}$ at $0.25 \mathrm{~g} / \mathrm{dm}^{3} \cdot \mathrm{h}$ and $\mathrm{r}_{\mathrm{DCW}}$ at ca. $1.2 \mathrm{~g} / \mathrm{dm}^{3} \cdot \mathrm{h}$ (Table 4). Glycerol consumption yield in both these variants approximated $3.8 \mathrm{~g} / \mathrm{dm}^{3} \cdot \mathrm{h}$ and $3.2 \mathrm{~g} / \mathrm{gDCW}$ (Table 4$)$. In the study by Chang et al. (2013) [67], increasing the value of $\mathrm{k}_{\mathrm{L}}$ a coefficient from $143 \pm 191 / \mathrm{h}$ to $568 \pm 241 / \mathrm{h}$ and $1805 \pm 1051 / \mathrm{h}$ resulted in DCW concentration exceeding $100 \mathrm{~g} / \mathrm{dm}^{3}$. 
Those authors also showed that the value of $\mathrm{k}_{\mathrm{L}}$ a coefficient affected assimilation of nutrients, microalgal biomass growth, and DHA synthesis.

Literature data and the present study results enable the conclusion that higher $\mathrm{k}_{\mathrm{L}}$ a values stimulate cell proliferation and lipid accumulation in microalgal biomass. The present study revealed very strong correlations between DCW, DHA, and lipid concentrations and $\mathrm{k}_{\mathrm{L}}$ a values (Figure 5). A further increase in the $\mathrm{k}_{\mathrm{L}}$ a value from $6001 / \mathrm{h}$ to $7501 / \mathrm{h}$ caused no statistically significant differences in the values of the analyzed parameters (Figures 4 and 5). However, the variant with $\mathrm{k}_{\mathrm{L}} \mathrm{a}=7501 / \mathrm{h}$ proved less technologically and economically viable.

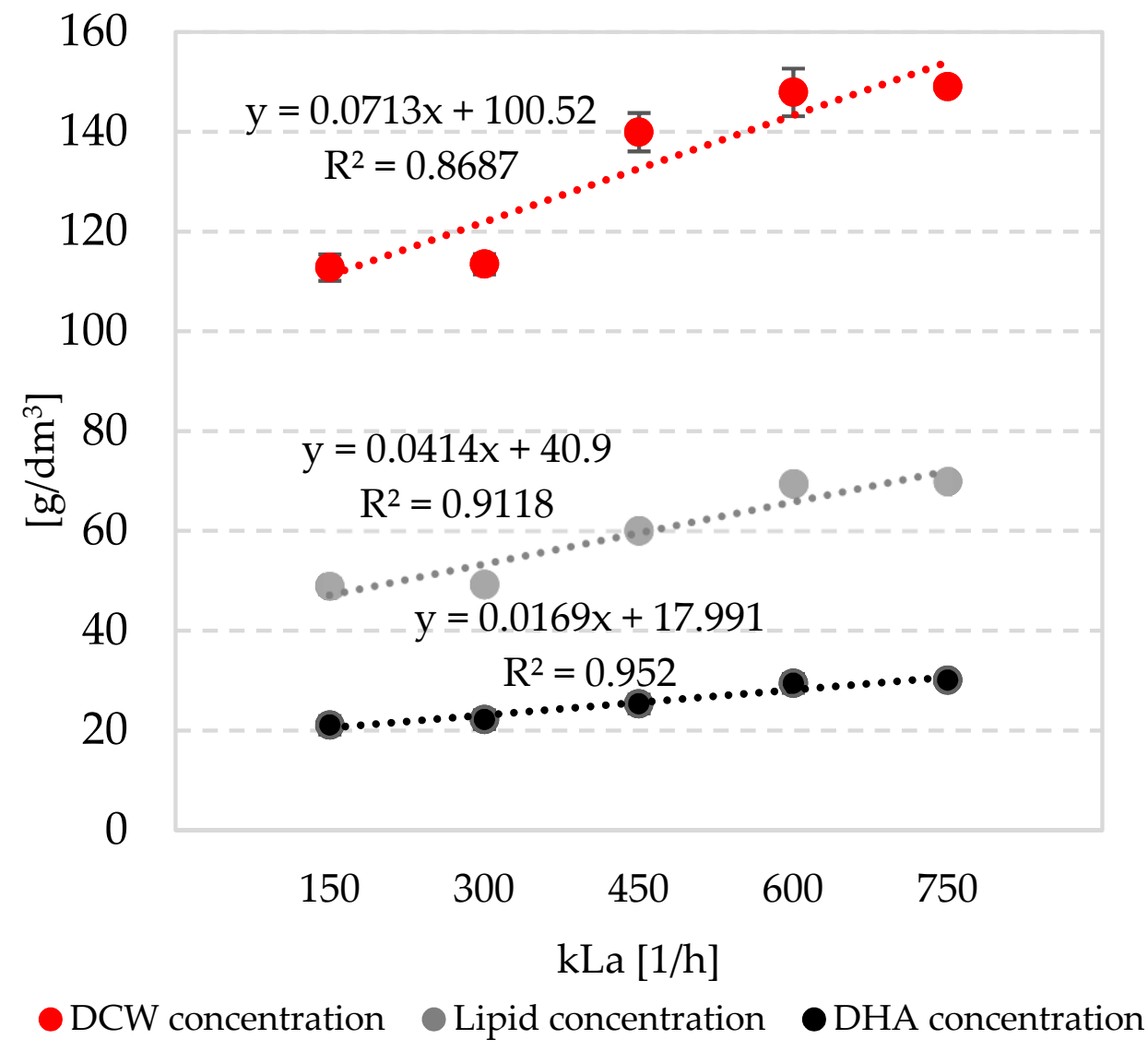

Figure 5. Correlations between DCW, DHA, and lipid concentrations and $\mathrm{k}_{\mathrm{L}}$ a values.

\section{Conclusions}

The Schizochytrium sp. biomass incubated in the culture with waste glycerol produced EPS, the highest concentration of which was determined in the stationary growth phase. Concentrations of saccharide monomers of the EPS fraction remained stable over the incubation period. The monosaccharides present in the EPS fraction included hexoses, except for xylose which is classified among pentoses. The major EPS component turned out to be glucose, with the concentration reaching $60.64 \pm 1.93 \% \mathrm{~mol}$.

EPS synthesized by Schizochytrium sp. biomass cause a significant increase in culture viscosity, which in turn contributes to diminished oxygen availability for the cells and to reduced effectiveness of waste glycerol utilization, lipid production, and DHA accumulation in cells.

Increased effectiveness of culture medium aeration boosts technological effects. The highest culture efficiency was observed with volumetric oxygen mass transfer of $k_{L} a=6001 / h$. The increase of its value to $7501 / \mathrm{h}$ did not cause any significant changes in the values of the analyzed parameters. This variant was not justified by either the technological effects achieved nor by the operating costs. Glycerol consumption was increased linearly depending on the applied oxygen mass transfer coefficient, ranging from $\mathrm{k}_{\mathrm{L}}$ a $1501 / \mathrm{h}$ to $\mathrm{k}_{\mathrm{L}}$ a $6001 / \mathrm{h}$. 
Author Contributions: Conceptualization, N.K., S.T. and M.D.; Data curation, M.D.; Formal analysis, M.D. and M.Z.; Funding acquisition, J.K. and M.Z.; Investigation, N.K., S.T. and M.D.; Methodology, N.K. and S.T.; Project administration, M.Z.; Resources, M.D. and J.K.; Software, N.K. and S.T.; Validation, M.Z.; Visualization, M.D. and J.K.; Writing-original draft, M.D. and J.K.; Writingreview and editing, M.D., J.K. and M.Z. All authors have read and agreed to the published version of the manuscript.

Funding: The manuscript was supported by Project financially supported by Minister of Education and Science in the range of the program entitled "Regional Initiative of Excellence" for the years 2019-2022, project No. 010/RID/2018/19, amount funding 12.000.000 PLN and the work WZ/WBIIŚ/2/2019, funded by Minister of Education and Science.

Institutional Review Board Statement: Not applicable.

Informed Consent Statement: Not applicable.

Data Availability Statement: Not applicable.

Conflicts of Interest: The authors declare no conflict of interest.

\section{References}

1. Yadav, A.K.; Rossi, W.; Habte-Tsion, H.-M.; Kumar, V. Impacts of dietary eicosapentaenoic acid (EPA) and docosahexaenoic acid (DHA) level and ratio on the growth, fatty acids composition and hepatic-antioxidant status of largemouth bass (Micropterus salmoides). Aquaculture 2020, 529, 735683. [CrossRef]

2. Tan, K.; Ma, H.; Li, S.; Zheng, H. Bivalves as future source of sustainable natural omega-3 polyunsaturated fatty acids. Food Chem. 2020, 311, 125907. [CrossRef] [PubMed]

3. Chandrasekaran, K.; Roy, R.K.; Chadha, A. Docosahexaenoic acid production by a novel high yielding strain of Thraustochytrium sp. of Indian origin: Isolation and bioprocess optimization studies. Algal Res. 2018, 32, 93-100. [CrossRef]

4. Shafiq, M.; Zeb, L.; Cui, G.; Jawad, M.; Chi, Z. High-Density pH-Auxostat Fed-Batch Culture of Schizochytrium limacinum SR21 with Acetic Acid as a Carbon Source. Appl. Biochem. Biotechnol. 2020, 192, 1163-1175. [CrossRef] [PubMed]

5. Hu, F.; Clevenger, A.L.; Zheng, P.; Huang, Q.; Wang, Z. Low-temperature effects on docosahexaenoic acid biosynthesis in Schizochytrium sp. TIO01 and its proposed underlying mechanism. Biotechnol. Biofuels 2020, 13, 1-14. [CrossRef]

6. Da Silva, T.L.; Moniz, P.; Silva, M.; Reis, A. The Dark Side of Microalgae Biotechnology: A Heterotrophic Biorefinery Platform Directed to $\omega$-3 Rich Lipid Production. Microorganisms 2019, 7, 670. [CrossRef]

7. Zhang, M.; Wu, W.; Guo, X.; Weichen, Y.; Qi, F.; Jiang, X.; Huang, J. Mathematical modeling of fed-batch fermentation of Schizochytrium sp. FJU-512 growth and DHA production using a shift control strategy. 3 Biotech 2018, 8, 162. [CrossRef]

8. Yin, F.-W.; Guo, D.-S.; Ren, L.-J.; Ji, X.-J.; Huang, H. Development of a method for the valorization of fermentation wastewater and algal-residue extract in docosahexaenoic acid production by Schizochytrium sp. Bioresour. Technol. 2018, 266, 482-487. [CrossRef]

9. Bi, Z.Q.; Ren, L.J.; Hu, X.C.; Sun, X.M.; Zhu, S.Y.; Ji, X.J.; Huang, H. Transcriptome and gene expression analysis of docosahexaenoic acid producer Schizochytrium sp. under different oxygen supply conditions. Biotechnol. Biofuels 2018, 11, 249. [CrossRef]

10. Dai, K.; Zhao, J.; Cheng, Y.; Tian, C.; Zhang, C.; Chen, M. Inulin as a Promising Alternative Feedstock for Docosahexaenoic Acid Production by Schizochytrium sp. ATCC 20888. Eur. J. Lipid Sci. Technol. 2020, 122, 2000079. [CrossRef]

11. Sun, X.-M.; Ren, L.-J.; Bi, Z.-Q.; Ji, X.-J.; Zhao, Q.-Y.; Jiang, L.; Huang, H. Development of a cooperative two-factor adaptiveevolution method to enhance lipid production and prevent lipid peroxidation in Schizochytrium sp. Biotechnol. Biofuels 2018, 11, 1-16. [CrossRef] [PubMed]

12. Dębowski, M.; Zieliński, M.; Kazimierowicz, J.; Kujawska, N.; Talbierz, S. Microalgae cultivation technologies as an oppor-tunity for bioenergetic system development-Advantages and limitations. Sustainability 2020, 12, 9980. [CrossRef]

13. Hu, X.; Tang, X.; Bi, Z.; Zhao, Q.; Ren, L. Adaptive evolution of microalgae Schizochytrium sp. under high temperature for efficient production of docosahexaeonic acid. Algal Res. 2021, 54, 102212. [CrossRef]

14. Kothri, M.; Mavrommati, M.; Elazzazy, A.M.; Baeshen, M.N.; Moussa, T.A.; Aggelis, G. Microbial sources of polyunsaturated fatty acids (PUFAs) and the prospect of organic residues and wastes as growth media for PUFA-producing microorganisms. FEMS Microbiol. Lett. 2020, 367, 1-11. [CrossRef]

15. Wang, X.-L.; Zhou, J.-J.; Shen, J.-T.; Zheng, Y.-F.; Sun, Y.-Q.; Xiu, Z.-L. Sequential fed-batch fermentation of 1,3-propanediol from glycerol by Clostridium butyricum DL07. Appl. Microbiol. Biotechnol. 2020, 104, 9179-9191. [CrossRef] [PubMed]

16. Seretis, A.; Tsiakaras, P. Hydrogenolysis of glycerol to propylene glycol by in situ produced hydrogen from aqueous phase reforming of glycerol over SiO2-Al2O3 supported nickel catalyst. Fuel Process. Technol. 2016, 142, 135-146. [CrossRef]

17. Kaur, J.; Sarma, A.K.; Jha, M.K.; Gera, P. Valorisation of crude glycerol to value-added products: Perspectives of process technology, economics and environmental issues. Biotechnol. Rep. 2020, 27, e00487. [CrossRef]

18. Dang, C.; Wu, S.; Cao, Y.; Wang, H.; Peng, F.; Yu, H. Co-production of high quality hydrogen and synthesis gas via sorptionenhanced steam reforming of glycerol coupled with methane reforming of carbonates. Chem. Eng. J. 2019, 360, 47-53. [CrossRef] 
19. Chiosso, M.E.; Casella, M.L.; Merlo, A.B. Synthesis and catalytic evaluation of acidic carbons in the etherification of glycerol obtained from biodiesel production. Catal. Today 2021, 372, 107-114. [CrossRef]

20. Bouriakova, A.; Mendes, P.S.; Katryniok, B.; De Clercq, J.; Thybaut, J.W. Co-metal induced stabilization of alumina-supported copper: Impact on the hydrogenolysis of glycerol to 1,2-propanediol. Catal. Commun. 2020, 146, 106134. [CrossRef]

21. Okhlopkova, E.A.; Serafimov, L.A.; Frolkova, A. Methods of Preparing Epichlorohydrin. Theor. Found. Chem. Eng. 2019, 53, 864-870. [CrossRef]

22. Bindea, M.; Rusu, B.; Rusu, A.; Trif, M.; Leopold, L.F.; Dulf, F.; Vodnar, D.C. Valorification of crude glycerol for pure fractions of docosahexaenoic acid and $\beta$-carotene production by using Schizochytrium limacinum and Blakeslea trispora. Microb. Cell Factories 2018, 17, 1-13. [CrossRef] [PubMed]

23. Mantzouridou, F.; Naziri, E.; Tsimidou, M.Z. Industrial Glycerol as a Supplementary Carbon Source in the Production of $\beta$-Carotene by Blakeslea trispora. J. Agric. Food Chem. 2008, 56, 2668-2675. [CrossRef] [PubMed]

24. Yu, K.O.; Jung, J.; Kim, S.W.; Park, C.H.; Han, S.O. Synthesis of FAEEs from glycerol in engineered Saccharomyces cerevisiae using endogenously produced ethanol by heterologous expression of an unspecific bacterial acyltransferase. Biotechnol. Bioeng. 2012, 109, 110-115. [CrossRef] [PubMed]

25. Bianco, F.; Race, M.; Forino, V.; Pacheco-Ruiz, S.; Rene, E.R. Bioreactors for wastewater to energy conversion: From pilot to full scale experiences. Waste Biorefinery 2021, 103-124. [CrossRef]

26. Dąbrowski, W.; Karolinczak, B.; Malinowski, P.; Boruszko, D. Modeling of Pollutants Removal in Subsurface Vertical Flow and Horizontal Flow Constructed Wetlands. Water 2019, 11, 180. [CrossRef]

27. Karolinczak, B.; Miłaszewski, R.; Dabrowski, W. Cost Optimization of Wastewater and Septage Treatment Process. Energies 2020, 13, 6406. [CrossRef]

28. Kazimierowicz, J.; Dzienis, L. Giant miscanthus as a substrate for biogas production. J. Ecol. Eng. 2015, 16, 139-142. [CrossRef]

29. Markowski, M.; Bialobrzewski, I.; Zielinski, M.; Dębowski, M.; Krzemieniewski, M. Optimizing low-temperature biogas pro-duction from biomass by anaerobic digestion. Renew. Energy 2014, 69, 219-225. [CrossRef]

30. Zieliński, M.; Rusanowska, P.; Dębowski, M.; Hajduk, A. Influence of static magnetic field on sludge properties. Sci. Total Environ. 2018, 625, 738-742. [CrossRef]

31. Bani, A.; Fernandez, F.G.A.; D'Imporzano, G.; Parati, K.; Adani, F. Influence of photobioreactor set-up on the survival of microalgae inoculum. Bioresour. Technol. 2021, 320, 124408. [CrossRef] [PubMed]

32. Park, H.; Kwak, M.; Seo, J.; Ju, J.; Heo, S.; Park, S.; Hong, W. Enhanced production of carotenoids using a Thraustochytrid microalgal strain containing high levels of docosahexaenoic acid-rich oil. Bioprocess Biosyst. Eng. 2018, 41, 1355-1370. [CrossRef] [PubMed]

33. Krzemieniewski, M.; Debowski, M.; Dobrzynska, A.; Zielinski, M. Chemical oxygen demand reduction of various wastewater types using magnetic field-assisted fenton reaction. Water Environ. Res. 2004, 76, 301-309. [CrossRef] [PubMed]

34. Guo, X.-L.; Ji, X.-J.; Ren, L.-J.; Li, G.-L.; Huang, H. Improving Docosahexaenoic acid production by Schizchytrium sp. using a newly designed high-oxygen-supply bioreactor. AIChE 2015, 63, 4278-4286. [CrossRef]

35. Ren, L.-J.; Ji, X.-J.; Huang, H.; Qu, L.; Feng, Y.; Tong, Q.-Q.; Ouyang, P.-K. Development of a stepwise aeration control strategy for efficient docosahexaenoic acid production by Schizochytrium sp. Appl. Microbiol. Biotechnol. 2010, 87, 1649-1656. [CrossRef] [PubMed]

36. Petersen, N.; Stocks, S.; Gernaey, K. Multivariate models for prediction of rheological characteristics of filamentous fermenta-tion broth from the size distribution. Biotechnol. Bioeng. 2008, 100, 61-71. [CrossRef]

37. Yao, C.; Zhao, Y.; Zheng, J.; Zhang, Q.; Chen, G. The effect of liquid viscosity and modeling of mass transfer in gas-liquid slug flow in a rectangular microchannel. AIChE J. 2020, 66, 66. [CrossRef]

38. Blunt, W.; Gaugler, M.; Collet, C.; Sparling, R.; Gapes, D.J.; Levin, D.B.; Cicek, N. Rheological Behavior of High Cell Density Pseudomonas putida LS46 Cultures during Production of Medium Chain Length Polyhydroxyalkanoate (PHA) Polymers. Bioeng. 2019, 6, 93. [CrossRef]

39. Bodie, E.; Virag, A.; Pratt, R.J.; Leiva, N.; Ward, M.; Dodge, T. Reduced viscosity mutants of Trichoderma reesei with improved industrial fermentation characteristics. J. Ind. Microbiol. Biotechnol. 2021, 48, kuab014. [CrossRef]

40. De Swaaf, M.E.; Grobben, G.J.; Eggink, G.; De Rijk, T.C.; Van Der Meer, P.; Sijtsma, L. Characterisation of extracellular polysaccharides produced by Crypthecodinium cohnii. Appl. Microbiol. Biotechnol. 2001, 57, 395-400.

41. Becker, A.; Katzen, F.; Pühler, A.; Ielpi, L. Xanthan gum biosynthesis and application: A biochemical /genetic perspective. Appl. Microbiol. Biotechnol. 1998, 50, 145-152. [CrossRef] [PubMed]

42. Xiao, R.; Yang, X.; Li, M.; Li, X.; Wei, Y.Z.; Cao, M.; Ragauskas, A.; Thies, M.; Ding, J.H.; Zheng, Y. Investigation of composi-tion, structure and bioactivity of extracellular polymeric substances from original and stress-induced strains of Thrausto-chytrium striatum. Carbohydr. Polym. 2018, 195, 515-524. [CrossRef] [PubMed]

43. Olvera-Sosa, M.; Rosales-Mendoza, S.; García-Briones, G.S.; Betancourt-Mendiola, M.D.L.; González-Ortega, O.; Palestino, G. A novel acrylic acid-Schizochytrium sp. bio-based polymer: Design, synthesis, and properties. Mater. Today Commun. 2021, 26, 102029. [CrossRef]

44. Garcia-Ochoa, F.; Gomez, E. Bioreactor scale-up and oxygen transfer rate in microbial processes: An overview. Biotechnol. Adv. 2009, 27, 153-176. [CrossRef] [PubMed] 
45. Sun, X.M.; Geng, L.J.; Ren, L.J.; Ji, X.J.; Hao, N.; Chen, K.Q.; Huang, H. Influence of oxygen on the biosynthesis of polyun-saturated fatty acids in microalgae. Bioresour. Technol. 2018, 250, 868-876. [CrossRef] [PubMed]

46. Kujawska, N.; Talbierz, S.; Dębowski, M.; Kazimierowicz, J.; Zieliński, M. Optimizing Docosahexaenoic Acid (DHA) Production by Schizochytrium sp. Grown on Waste Glycerol. Energies 2021, 14, 1685. [CrossRef]

47. Kujawska, N.; Talbierz, S.; Dębowski, M.; Kazimierowicz, J.; Zieliński, M. Cultivation Method Effect on Schizochytrium sp. Biomass Growth and Docosahexaenoic Acid (DHA) Production with the Use of Waste Glycerol as a Source of Organic Carbon. Energies 2021, 14, 2952. [CrossRef]

48. Underwood, G.J.C.; Paterson, D.M.; Parkes, R.J. The measurement of microbial carbohydrate exopolymers from intertidal sediments. Limnol. Oceanogr. 1995, 40, 1243-1253. [CrossRef]

49. Dubois, M.; Gilles, K.; Hamilton, J.; Reberes, P.; Smith, F. Colorimetric method for determination of sugars and related sub-stances. Anal. Chem. 1956, 28, 350-356. [CrossRef]

50. Chaplin, M.; Kennedy, J. Carbohydrate Analysis: A practical Approach; IRL Press: Oxford, UK, 1986.

51. Kucuk, C.; Merih, K. Extracellular polysaccharide production by Rhizobium ciceri from Turkey. Ann. Microbiol. 2009, 59, 141-144. [CrossRef]

52. Nouha, K.; Kumar, R.S.; Ram, S.K.; Tyagi, R.D. Critical review of EPS production, synthesis and composition for sludge flocculation. J. Environ. Sci. 2018, 66, 225-245. [CrossRef]

53. Mancuso, N.; Browman, J.; Guezennec, J. Effects of incuba- tion temperature on growth and production of exopolysaccha-rides by an Antarctic sea ice bacterium grown in batch culture. Appl. Environ. Microbiol. 2005, 71, 3519-3523.

54. Yin, W.; Wang, Y.; Liu, L.; He, J. Biofilms: The Microbial “Protective Clothing” in Extreme Environments. Int. J. Mol. Sci. 2019, 20, 3423. [CrossRef]

55. Bhaskar, P.; Bhosle, N. Microbial extracellular polymeric substances in marine biogeochemical processes. Curr. Sci. 2005, 88, $45-53$.

56. Jaroszuk-Ściseł, J.; Nowak, A.; Komaniecka, I.; Choma, A.; Jarosz-Wilkołazka, A.; Osińska-Jaroszuk, M.; Tyśkiewicz, R.; Wiater, A.; Rogalski, J. Differences in Production, Composition, and Antioxidant Activities of Exopolymeric Substances (EPS) Obtained from Cultures of Endophytic Fusarium culmorum Strains with Different Effects on Cereals. Molecules 2020, 25, 616. [CrossRef]

57. Kumar, D.; Kastanek, P.; Adhikary, S.P. Exopolysaccharides from cyanobacteria and microalgae and their commercial ap-plication. Curr. Sci. 2018, 115, 234. [CrossRef]

58. Delattre, C.; Pierre, G.; Laroche, C.; Michaud, P. Production, extraction and characterization of microalgal and cyanobacterial exopolysaccharides. Biotechnol. Adv. 2016, 34, 1159-1179. [CrossRef] [PubMed]

59. Markou, G.; Nerantzis, E. Microalgae for high-value compounds and biofuels production: A review with focus on cultivation under stress conditions. Biotechnol. Adv. 2013, 31, 1532-1542. [CrossRef] [PubMed]

60. Pierre, G.; Delattre, C.; Dubessay, P.; Jubeau, S.; Vialleix, C.; Cadoret, J.-P.; Probert, I.; Michaud, P. What Is in Store for EPS Microalgae in the Next Decade? Molecules 2019, 24, 4296. [CrossRef] [PubMed]

61. Jain, R.; Raghukumar, S.; Tharanathan, R.; Bhosle, N. Extracellular polysaccharide production by thraustochytrid protists. Mar. Biotechnol. 2005, 7, 184-192. [CrossRef] [PubMed]

62. Chang, G.; Wu, J.; Jiang, C.; Tian, G.; Wu, Q.; Chang, M.; Wang, X. The relationship of oxygen uptake rate and kLa with rheological properties in high cell density cultivation of docosahexaenoic acid by Schizochytrium sp. S31. Bioresour. Technol. 2014, 152, 234-240. [CrossRef] [PubMed]

63. Zhou, X.; Zhou, X.; Xu, Y. Improvement of fermentation performance of Gluconobacter oxydans by combination of enhanced oxygen mass transfer in compressed-oxygen-supplied sealed system and cell-recycle technique. Bioresour. Technol. 2017, 244, 1137-1141. [CrossRef] [PubMed]

64. Qu, L.; Ji, X.-J.; Ren, L.-J.; Nie, Z.-K.; Feng, Y.; Wu, W.-J.; Ouyang, P.-K.; Huang, H. Enhancement of docosahexaenoic acid production by Schizochytrium sp. using a two-stage oxygen supply control strategy based on oxygen transfer coefficient. Lett. Appl. Microbiol. 2010, 52, 22-27. [CrossRef]

65. Yang, X.; Xu, T.; Cao, P.; Qiao, K.; Wang, L.; Zhao, T.; Zhu, J. The viscosity behaviors of bacterial suspensions or extracellular polymeric substances and their effects on aerobic granular sludge. Environ. Sci. Pollut. Res. 2019, 26, 30087-30097. [CrossRef] [PubMed]

66. Jakobsen, A.; Aasen, I.; Strom, A. Endogenously synthesized (-)-proto-quercitol and glycine betaine are principal compatible solutes fo Schizochytrium sp. strain S8 (ATCC 20889) and three new isolates of phylogenetically related thraustochytrids. Appl. Environ. Microbiol. 2007, 73, 5848-5856. [CrossRef] [PubMed]

67. Chang, G.; Gao, N.; Tian, G.; Wu, Q.; Chang, M.; Wang, X. Improvement of docosahexaenoic acid production on glycerol by Schizochytrium sp. S31 with constantly high oxygen transfer coefficient. Bioresour. Technol. 2013, 142, 400-406. [CrossRef] 